DOI: $10.20472 / B M .2015 .3 .1 .008$

\title{
A CREATING BUSINESS FROM INNOVATIONS - ESSENTIAL MISSION OF INTERMEDIATE ORGANIZATION
}

\author{
PEKKA TERVONEN, HARRI HAAPASALO
}

\begin{abstract}
:
Oulu Innovation Alliance (OIA) is an example of triple-Helix consortium. It integrates top know-how from printed intelligence, wellbeing technology, cleantech and 3D internet and brings together research institutions, businesses and public sector organizations. OIA generates cutting-edge global business from research, development and innovation projects and ventures. The essential mission of the Centre for Environment and Energy (CEE) is to be strongly involved in branding Oulu as an eco-innovative city with green economy. The focus of CEE is on air, water, energy and efficiency of resources with measurement technology as a cross-sectional theme. Their vision is to be the number one partner in eco-innovative solutions. The strategy is to develop a knowledge hub that brings together the fields of environment and energy, thus, creating efficient connections between top experts and research, development and innovation projects (R\&D\&I projects); and co-operation networks and investors. To achieve this goal, the CEE uses a transparent network of connections where the top research of a chosen field and the business expertise in Oulu can find each other both nationally and internationally. This creates a lasting foundation for co-operation between research and business. The operational philosophy of CEE is based on research programs and networking which allows for swift and proactive co-operation between research communities and businesses. Through co-operation and joint projects new expertise can be develop edand new business created for the world market. The aim of this paper is to describe the theoretical foundation and operative model for our centre of expertise - CEE.
\end{abstract}

\section{Keywords:}

Innovations, environment, energy, cleantech

JEL Classification: 032

\section{Authors:}

PEKKA TERVONEN, University of Oulu, Finland, Email: pekka.tervonen@oulu.fi HARRI HAAPASALO, University of Oulu, Finland, Email: harri.haapasalo@oulu.fi

\section{Citation:}

PEKKA TERVONEN, HARRI HAAPASALO (2015). A creating business from innovations - essential mission of intermediate organization. International journal of Business and Management, Vol. III(1), pp. 119-131., 10.20472/BM.2015.3.1.008 


\section{Introduction}

An economic situation and accelerating technological development has changed industrial structures both globally and locally. Previously, industrial development was predominantly based on the natural resources available in the region. During the last few decades, however, industrial positions have been increasingly obtained by new technology-based firms, no matter what area of industry we are discussing. Technological skills and capabilities have become more critical factors in regional development, which now consequently is tightly connected to the technological development and the economy of the region, as well as to the regional ability to seize the opportunities and convert these technological skills into new products and services. Basic technological skills and capabilities are brought about in research institutes and universities, while enterprises are the actors which apply and utilize this knowledge. In this type of development process, interaction between the HEls (Higher Education Institutes) and the firms is crucial. The interaction is strongly influenced by regional and national cultures and policies.

The aim of this paper is to describe the theoretical foundation and operative model for our centre of expertise - CEE. We first review the diversified literature behind strategy and operations of these centres of expertise. Then we outline the operation of CEE - example of a centre of expertise, finally to describe the future avenues of CEE.

\section{Innovation activity and business development}

An innovation activity should be seen as a large entity. In addition to new projects and processes, new technology may bring along new features and market opportunities. Business development must, therefore, be considered to be an important part of innovation activities (Drejer, 2002). A business model must adapt to changes arising from innovations. The value of an innovation cannot be delivered or achieved without a business model (Teece, 2010). Technology generates less value, if a suitable business model cannot be found for it (Chesbrough, 2010). Technological innovations must often be launched on the markets and the new needs of customers must be met. As a consequence, a suitable business model is also required (Teece, 2010).

The business operations of a company are typically based on a business model, and every enterprise has its own model, be it intentional or unintentional (Chesbrough, 2007). A business model does not, however, equal a strategy. A mere business model is not enough to succeed in fiercely competitive markets; a strategy states the areas, in which the company intends to exceed or differ from its competitors. (Magretta, 2002.) According to Pekuri et al. (20013, 2014), a business model can describe business as a system, business model is also used to describe how to implement strategy. 
A company's business model may present an outlook on how the company creates and produces value for its customers (Teece, 2010). Business models can also be used to identify the core parts of the company's business and their relations (Osterwalder et al., 2005). From the company's point of view, business models have two important functions: a creation of value and assuming value (Chesborough, 2007). According to Teece (2010), a business model describes the company's value creation system, how the company delivers value and benefits from it. Therefore our current paper examines the offering, value creation system and revenue logic of business models.

An offering refers to the end product of a value creation chain. Through its offering, a company can create value for its customers, for example, by the means of products, services, knowledge or a combination of these. (Kotler, 1997). The value creation system is based on a value chain. Porter (1985) uses the term 'value chain' to describe a system in which a company designs, manufactures, markets and delivers its products. Revenue logic describes where and how a company generates its profit (Rajala et al., 2001).

Creativity, ideas and innovations are concepts that are often used in the same context. According to Schilling (2008), an idea is a concept which has been imagined or outlined in one's own mind. According to Damanpour et al., (2009) an idea can be attributed to new products, processes, markets or administrative structures or even on business model (Osterwalder et al., 2005). Fairbank et al, (2003) describes creativity as solving problems with new, practical solutions. Creativity can be defined as the generation of ideas and innovation can, then, be understood as the processing of these ideas (Alves et al., 2007). In business, creativity often refers to ideas that give rise to new product or process innovations (Gordon et al., 2008). Creativity is, therefore, strongly linked with innovation, also in the field of business. It is also important to note that innovation creates change in one area of business model and then leads on a change in others also.

There are a number of definitions for innovation. According to Gopalakrishnan and Damanpour (1997), innovation, at its simplest, means something new, whereas McAdam and McClelland (2002) consider innovation to be a gradual process stretching from the creation of an idea to its practical implementation. In their view, creativity is part of the idea creation process. Innovation is also often connected with invention, which is often considered to be a short, once-off event. According to Garcia and Calantone (2002), in addition to a product development process, innovation can occur in processes that entail continuous improvements or modernisations.

In terms of business, innovation is often connected with commercial and technological aspects. Innovation requires the exploitation of ideas and the commercialisation of inventions (Drejer, 2002). It is often also described as a change, which a company can offer as an actual product or as a process innovation, which means the way a company produces the product it offers to its customers (Francis \& Bessant, 2005). According to Fairbank and Williams (2001), 
the impacts of innovations may cover everything from new products to minor improvement in processes.

One of the most commonly used ways is perhaps to consider innovations to be a part of process and product innovations, as was also stated by Francis and Bessant (2005). According to Gopalakrishnan et al. (1999), process and product innovations are related to know-how, which is a part of the systems, methods and individual employees of an organisation. The difference between process and product innovation is the target of the innovation (Gopalakrishnan \& Damanpour, 1997). According to Damanpour and Gopalakrishnan (2001), innovations which are related to products and technologies affect industries, whereas process innovations are primarily targeted at specific organisations. Garcia and Calantone (2002) state that the difference between process and product innovation is often difficult to define, because product innovations may have their origins in process innovations.

According to Garcia and Calantone (2002), innovativeness often refers to the novelty of an innovation, but one seldom pays attention to whose viewpoint the novelty is assessed. According to Drejer (2002), one possible way to assess the novelty of an innovation is to examine it from the viewpoint of the company and its field of industry. In addition, an innovation can be new to the individual, organisation or industry who are applying the said innovation (Damanpour et al., 2009). According to Carcia and Calantone (2002), innovativeness can be examined - regardless of one's viewpoint - as the degree of change in a technology or the markets.

Drejer (2002), however, describes innovation as a result of an innovation process. The entire innovation process must be included into the company's strategy, in order for the company to guarantee a continuous flow of innovations (Koen et al., 2001). Koen et al. (2001) describes a three-stage innovation process that starts from the onset of the process, continues towards a systematic product or process development stages and terminates in a commercialisation. For example, the innovation process described by Koen et al. (2001) divides the process into three sub-processes defined in the literature and it is, therefore, an illustrative example of the innovation process. Tidd et al. (2005) presents a general model of four common tasks in the innovation process of a company: 1) The company must observe its environment for innovation opportunities, 2) The company must choose the most lucrative opportunities to enhance its competitiveness, 3) The company must implement the chosen opportunities and develop them into products or processes and 4) The company must monitor the previous stages and collect and exploit information gathered from various stages in order to develop the process.

According to Khurana and Rosenthal (1998), the holistic innovation process management is based on creating connections between business, product strategy and decision-making during the early phases of an innovation process. Decision-making in the early phases of an 
innovation process should be based on the company's strategy (Khurana \& Rosenthal, 1998). According to Broeddrich (2004), innovations are considered to be successful in so far as they are linked to the company's strategy at an early stage and if the ideas which are suggested result in products that have clear advantages to competing products. Kim and Wilemon (2002a) also state that the early phases of an innovation process must be in accordance with the company's strategy and existing capabilities. A successful product development process can only be achieved if the early phases of the innovation process are based on the company's capabilities (Koen et al., 2001). Khurana and Rosenthal (1998) also underline the importance of integrating a business and product strategy on the early phases of an innovation process, for example, in creating product definitions. New products must be supported by development plans and testing and as possible new business (Khurana \& Rosenthal, 1998).

According to Koen et al. (2001), the greatest improvement opportunities of an innovation process can be found during the early phases of the innovation process. According to Kim and Wilemon (2002b), the early phases of an innovation process consist of the recognition of an opportunity and the making of the decision to develop it further. According to Koen et al. (2001), however, the early phases of an innovation are actions which precede the formal project development of a product development process. The successful management of the early phases of an innovation process, therefore, includes an understanding of the form of the process and the consequences of actions taken within the process (Kim \& Wilemon, 2002b).

The importance of the early phases of an innovation process is highlighted since it precedes actual product or process development processes (Koen et al. 2001). The R\&D of the company benefits from a good organisation of the early phases of an innovation process, and its results affect any later stages of the process (Kim \& Wilemon, 2002a).

For Koen et al. (2001), the early phases of an innovation process are informal and unpredictable. The early phases of an innovation process could also be described as being creative actions or actions aimed at formulating an idea - through various stages - into a development proposal (Gordon et al., 2008). Boeddrich (2004) state that the early phases of an innovation process are considered to be informal and unpredictable, due to the impacts of creative elements on the innovation process. The early phases of an innovation process are challenging, as it is susceptible to great uncertainty and expectations, in addition to which, the skills and operating models of the various parts of an organisation merge during the early phases of the process (Khurana \& Rosenthal, 1998). Uncertainty is underlined in the cases of new products or changes in the markets, for example (Kim \& Wilemon, 2002a).

Also, Koen et al. (2001) say that the company's strategy, competition and the company's capabilities and technology affect the onset of an innovation process. According to Khurana and Roselthal (1998), if a company wishes to make the early phases of an innovation process more effective, the company must focus on the strategy, culture, processes and roles. The 
company must adapt its process to match the products, markets and its own organisation (Khurana \& Rosenthal, 1998).

According to Koen et al., (2001), the five elements of the early phases of an innovation process are: the identification of an opportunity, the analysis of the opportunity, the generation of an idea, selecting the idea to further development, and the development of a concept and technology. These five elements are included in a new concept development model by Koen et al. (2001). The underlying force, engine, of the model is support by the company management, whereas the outer circle consists of external factors that influence decisionmaking in other components. (Koen et al., 2001)

Companies often identify opportunities that they want to exploit in line with their business goals. The opportunities may vary from minor improvements to major overhauls (Koen et al., 2001). During an innovation process, companies must observe their environment, in order to identify threats and opportunities (Tidd et al., 2005).

A company then examines an opportunity that it has identified, obtains further information and, if required, invests additional resources in its analysis, in order to better assess the impacts of the opportunities which have been identified for, among others, its business (Koen et al., 2001).

An opportunity is developed into an idea and during the idea generation phase described by Koen et al. (2001), an opportunity evolves into a concrete idea. The process may be repeated several times and ideas are used to generate, analyse, combine, process and update other ideas. This phase may include idea banks and brainstorming operations, which are used to develop and collect new ideas or further develop existing ones. (Koen et al., 2001.)

Due to the large number of ideas generated, selecting the right one is often challenging for the company. In order to identify viable ideas that are useful to the company's business, they must be examined from the viewpoints of the company's capabilities, competition, available technology and markets, for example. (Koen et al., 2001.) As an idea becomes better defined and less unclear, it usually moves onto the development stage (Kim \& Wilemon, 2002b). The concept is further developed and its business opportunities and risks are assessed. The development of the concept can be organised in various ways, depending on how much resources it requires and what kind of a company is exploiting the concept. (Koen et al., 2001.)

\section{Oulu model for eco-innovations}

\section{OIA - unique co-operation}


The Oulu Innovation Alliance, OIA, is a strategic agreement made in 2009 between the City of Oulu, University of Oulu, Oulu University of Applied Sciences, VTT and Technopolis Ltd. The purpose of this Alliance is first and foremost to continue Oulu's long tradition in maintaining co-operation between education, research and business, as well as, the public sector. The goal of the Innovation Alliance is to keep Oulu on the world map as an outstanding innovation centre. This combination could in principle be perceived as a variant of the so-called Triple Helix. "The triple helix denotes the university-industry-government relationship as one of relatively equal, yet interdependent, institutional spheres which overlap and take the role of the other ... Bilateral relations between government and university, academia and industry have expanded into triadic relationships among the spheres, especially at the regional level. Academic-industry-government relations are emerging from different institutional starting points in various parts of the world, but for the common purpose of stimulating knowledgebased economic development." (Etzkowitz 2002). Ylinenpää (2001) states: "To be able to compete successfully on the market to an increasing extent requires a close co-operation between industry and different specialised knowledge centres such as universities and other HEls. This co-operation however also involves (state, regional and local) government, since public and semi-public bodies often represent both a market, a source for financing, and have the power to influence the conditions for specific innovative activities."

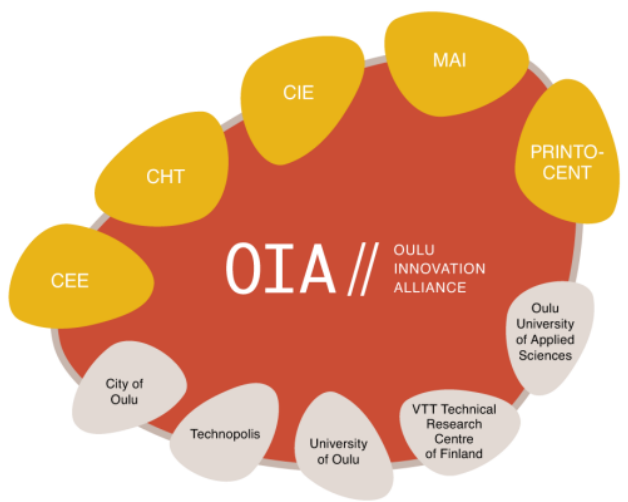

Figure 1 Oulu Innovation Alliance

"We wanted to create a co-operational structure in which the public sector, business and research communities meet at the same table", says Rector Lajunen. "The aim is to strengthen strategic co-operation and put innovations into work. Co-operation of this kind is genuinely unique."

The founding members of the OIA have committed to focus their functions on the agreed areas of innovation, invest in agreed infrastructures and develop mechanisms for common use. The target areas are Internet and 3D research $(\mathrm{CIE})$, printed intelligence (PrintoCent), health and well-being technology (CHT), environment and energy (CEE) and international business (MAl). 
"The members of the Innovation Alliance have a long tradition of co-operation and strong mutual trust and commitment to common goals", tells Matti Pennanen, the Mayor of Oulu.

Pennanen says that Oulu is just the right size operating platform even for international companies - small enough and at the same time sufficiently big for easily connecting different know-how and business areas. "On one hand the University, VTT and the University of Applied Sciences have always greatly influenced on creating new business, OIA on the other swiftly finds the right connections between business know-how and top research."

Rector Lajunen in turn touts the know-how in Oulu: "Know-how and idea generation together bring success to research and businesses and work for the people in Oulu."

\section{Oulu's cleantech know-how in a league of its own}

Oulu invests heavily in developing cleantech that is a global and fast growing industry. Cleantech products from Oulu are in use all over the world: from cleaning sewage water in European holiday destinations and exhaust gases in Hongkong to producing intelligent lighting for service stations in Finland and green electricity in France. Cleantech businesses create solutions that help to decrease hazardous environmental effects and improve environmental quality. The aim of these technological, product or service solutions is minimal strain on the environment along with energy efficiency and economical use of raw materials.

Oulu's strong areas of know-how are in emission control, renewable energy and energy efficiency, material flows, and the city of Oulu cleantech ecosystem. Oulu wants to promote the use of cleantech solutions and also take into account energy saving and the environmental effects. Lauri Lajunen, Rector of the University of Oulu, reminds that the advancement of the Oulu cleantech is greatly supported by the strong ICT know-how in the area - this and the wide environmental know-how are a way to the future. Creative utilisation of the wireless technology in particular, generates entirely new applications.

\section{CEE, the newest innovation centre in Oulu, challenges the experts in green business}

CEE builds bridges - it brings together experts and believes in new ideas! CEE, the Centre for Environment and Energy makes new things happen in the environment and energy business.

"With the eco innovations we are putting Oulu on the world map; we are making business green and green into business", says Pekka Tervonen Director of the CEE. "We work as a link between the businesses and research and product development. This way we can 
promote internationally interesting trade and business." CEE is an innovation hub that gathers the best experts together and promptly commercialises the ideas from business and research. A decision on a project start is made within two weeks.

CEE's strength comes from 300 researchers, 200 projects and nearly 100 businesses around the area. University Environment House is located at the same campus with Nornet, Lynet, Thule Institute, University of Oulu, VTT and Technopolis, together with other environment and energy related businesses.

We will give wings to innovations - air, water, energy, resource efficiency and measurement technology can be turned into functional products. That's what we are here for. We will head for the international arenas right away. The water alone holds a billion euro market. Our goal is to make eco innovations and green economy a brand for Oulu. You, Oulu and Finland can be the global forerunners.

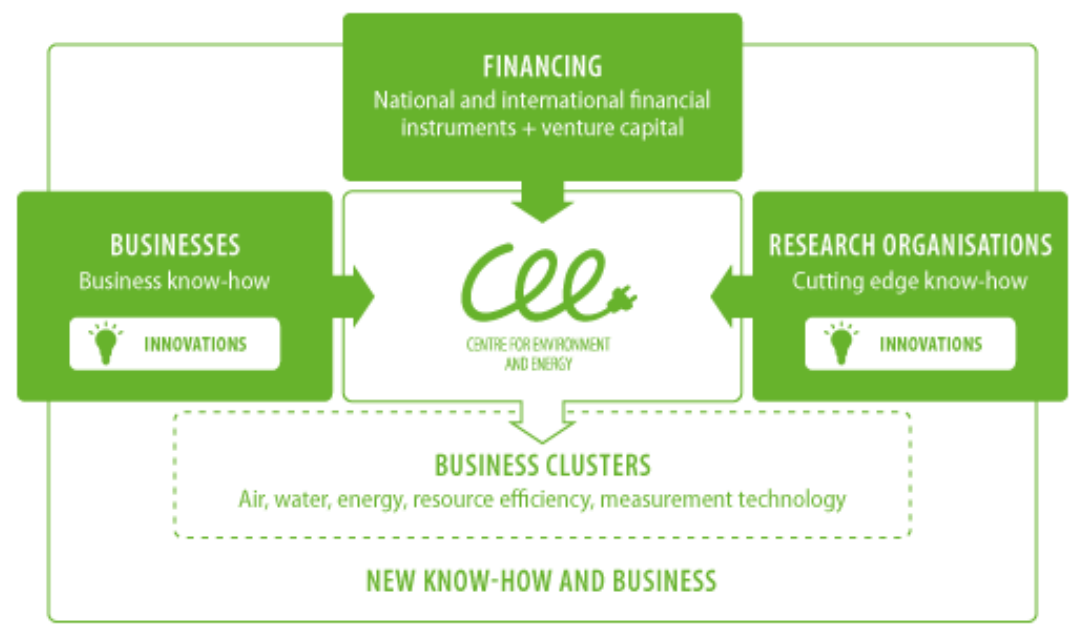

Figure 2. Eco-Innovations - a brand for Oulu

\section{CEE - a leader in numerous projects}

The CEE grant was awarded to the Optoelectronics and Measurement Technology Laboratory. Under the supervision of Adjunct Professor Tapio Fabritius the laboratory is developing polymer based solar cell technology for the distributed electricity production applications.

The Smarctic project is preparing a strategic research for Tekes called, "Road map for smart Arctic specialisation". The project focuses on how the Arctic's natural resources and new 
transport routes can be sustainably utilised. It also looks into the possibilities related in renewing economy and business.

The ERDF funded RAE project (Granulation enhances ecological friendliness) forms a research basis for developing new business opportunities. One vision is a chain of businesses that could develop a new product from bio ash. This would be used as an adsorbent, absorbing nutrients, to treat sewage water, and the bio ash product could be used e.g. for forest fertilisation.

\section{CEE - partner to many businesses}

"CEE has helped to implement projects and find the right contacts in Finland and even internationally", says Saku Kaukonen, Acting CEO and CTO at Sapotech. Sapotech Ltd provides innovative quality control solutions for high temperature processes in the steel, metal and energy industry. Sapotech's solutions utilise the latest technologies in machine vision, devices and software.

"CEE skilfully connects the business experts and the top research in the area; for businesses it creates new innovations and products that are competitive in the international market", tells Jaakko Pellinen, CEO of OWA. One key task of the Oulu Water Alliance Ltd (OWA) is to bring together the water know-how in co-operation with CEE. OWA provides advanced water treatment solutions and services e.g. for the mining and steel industry and the municipal water operators. OWA also offers expert, research and development services within the water industry.

"Co-operation with CEE has been easy. We have the same clear mission, goals and most of all motivation", says CEO Teemu Leskinen at Rakeistus Oy. Rakeistus Oy develops innovative and mobile granulation systems for the utilisation of bio ash. Rakeistus Oy and CEE both participate in the RAE project that in co-operation improves material efficiency. The Rakeistus Oy slogan is very fitting: "Granulation is sustainability".

\section{Conclusion - the future is bright}

The mission of CEE is to be involved in making eco innovations and green economy a brand for Oulu. Our strategy is to develop a knowledge hub that brings together the fields of environment and energy, thus, creating efficient connections between top experts and R\&D\&I projects; and co-operation networks and investors. CEE builds business clusters for the focus areas of air, water, energy, instrumentation and the efficiency of resources. CEE establishes transparent networks in Oulu, Finland and the world. Our operational philosophy is based on research programmes and networking with an emphasis on speed, transparency and the cooperation between businesses and the scientific world. This co-operation will bring cutting 
edge know-how and business for into the international market. Our vision is to be the number one partner in eco-innovative solutions.

\section{References}

Alves J, Marques MJ, Saur I \& Marques P (2007) Creativity and Innovation through Multidisciplinary and Multisectoral Cooperation. Creativity and Innovation Management 16(1):27-34.

Boeddrich H-J (2004) Ideas in the Workplace: A New Approach Towards Organizing the Fuzzy Front End of the innovation Process. Creativity and Innovation Management 13(4): 274-285.

Chesbrough H (2007) Business model innovation it's not just about technology anymore. Strategy \& Leadership 35(6):12-17.

Chesbrough H (2010) Business Model Innovation, Opportunities and Barriers, Long Range Planning 43(2-3):354.

Damanpour F, Walker RM \& Avellaneda CN (2009) Combinative Effects of Innovation Types and Organizational Performance A Longitudinal Study of Service Organizations. Journal of Management Studies 46(4): 650-675.

Damanpour F \& Gopalakrishnan S (2001) The Dynamics of the Adoption of Product and Process Innovations in Organizations. Journal of Management Studies, 38(1): 45-65.

Drejer A (2002) Situations for innovation management: Towards a contingency model. European Journal of Innovation Management. 5(1): 4-17.

Etzkowitz, H. 2002. The Triple Helix of University - Industry - Government. Implications for Policy and Evaluation. Sweden, Stockholm. Science Policy Institute. 17 p.

Fairbank JF, Spangler WE \& Williams SD (2003) Motivating creativity through a computermediated employee suggestion management system. Behaviour \& Information Technology 22(5):305-14.

Fairbank JF \& Williams SD (2001) Motivating Creativity and Enhancing Innovation through Employee Suggestion System Technology. Creativity and Innovation Management 10(2): 68-74.

Francis D \& Bessant $J$ (2005) Targeting innovation and implications for capability development. Technovation 25(19): 171-183.

Garcia R \& Calantone R (2002) A Critical look at technological innovation topology and innovativeness: a literature review. The Journal of Product Innovation Management 19(2): 110-132.

Gopalakrishnan S \& Damanpour F (1997) A review of innovation research in economics, sociology and technology management. Omega 25(1): 15-28.

Gopalakrishnan S, Bierly P \& Kessler EH (1999) A Re-examination of product and process innovations using a Knowledge-Based view. The Journal of High technology management research 10(1):147-166. 
Gordon S, Tarafdar M, Cook R, Maksimoski R \& Rogowitz B (2008) Improving The Front End of Innovation With Information Technology. Research Technology Management 51(3):5058.

Gorski C \& Heinekamp EJ (2002) Capturin employee ideas for new products. In: Belliveau P, Griffin A \& Somermeyer S (2002) The PDMA toolbook for new product development. Wiley \& Sons, New York.

Järvinen P \& Järvinen A (2000) Tutkimustyön metodeista. Tampere: Opinpaja Oy 211 s.

Kasanen E, Lukka K, \& Siitonen A (1993) The constructive approach in management accounting research. Journal of Management Accounting Research 5: 243-264.

Kaplan RS \& Norton DP (2004) Strategy Maps: converting intangible assets into outcomes. Harvard Business School.

Khurana A \& Rosenthal SR (1998) Towards holistic "front ends" in new product development. Journal of Product Innovation Management 15(1): 57-74.

Kim J, Wilemon D (2002a) Strategic issues in managing innovation's fuzzy front-end. European Journal of Innovation Management 5(1):27-39.

Kim J \& Wilemon D (2002b) Focusing the fuzzy front-end in new product development. R\&D Management, 32(4): 269-279.

Koen P, Ajamian G, Burkart R, Clamen A, Davidson J, D'Amore R, Elkins C, Herald K, Incorvia M, Johnson A, Karol R, Seibert R, Slavejkov A \& Wagner K (2001) Providing clarity and a common language to the fuzzy front end. Research Technology Management. 44(2): 46-55.

Kotler P (1997) Marketing Management: Analysis, Planning, Implementation, and Control. 11th ed. Upper Saddle River: Prentice-Hall International, Inc.

McAdam R \& McClelland $J$ (2002) Individual and team-based idea generation within innovation management: Organisational and research agendas. European Journal of Innovation Management 5(2): 8697.

Magretta J (2002) Why Business Models Matter. Harvard Business Review 80(5):86-92.

Osterwalder A, Pigneur Y \& Tucci CL (2005) Clarifying Business Models Origins, Present, and Future of the Concept. Communications of the Association for Information Systems 16(1):1-25.

Pekuri A, Pekuri L \& Haapasalo H (2013) The role of business models in Finnish construction companies. Australasian Journal of Construction Economics and Building 13(3): 13-23.

Pekuri A, Suvanto M, Haapasalo H \& Pekuri L (2014) Managing value creation: the business model approach in construction. International Journal of Business Innovation and Research 8(1): 36-51.

Porter ME (1985) Competitive Advantage: Creating and Sustaining Superior Performance, New York: The Free Press.

Rajala R, Rossi M, Tuunainen V, Rautiainen K \& Korri S. (2001) 'Software business models: a framework for analyzing software industry'. Technology Review, Helsinki: TEKES.

Rapp C \& Eklund J (2002) Sustainable development of improvement. Total Quality Management 13(7): 945- 969. 
Schilling MA (2008) Strategic management of technological innovation. 2nd edition. McGrawHill.

Tarafdar M \& Gordon SR (2007) Understanding the influence of information systems competencies on process innovation: A resource-based view. Journal of Strategic Information Systems 16(4):353-392.

Tervonen P, Alapiha J \& Haapasalo H (2009) Benchmarking ESSQ management system through tailored maturity model. International Journal of Management \& Enterprise Development 7(3): 262-280.

Teece DJ (2010) Business Models, Business Strategy and Innovation. Long Range Planning 43: $172-194$.

Tidd J, Bessant J, \& Pavitt K (2005) Managing Innovation. Integrating technological, market and organizational change. 3rd edition, Wiley, 2005.

Tonnesen T (2005) Continuous innovation through company wide employee participation. The TQM Magazine 17(2): 195-207.

Yin RK (2003) Case Study Research: Design and Methods. 3rd ed. Thousand Oak, California: Sage Publications.

Ylinenpää, H. 2001. Co-operation, Trust and Triple Helixes in a Northern Dimension. Thinktank seminar, Björkliden Sweden, June 14-17, 2001. 